\title{
SINTESIS MEMBRAN SELULOSA ASETAT CASSAVA UNTUK MIKROFILTRASI Fe PADA LIMBAH BATIK ARTIFISIAL
}

\author{
Harianingsih", Farikha Maharani \\ Jurusan Teknik Kimia, Fakultas Teknik, Universitas Wahid Hasyim \\ J1. Menoreh Tengah X/22 Sampangan, Semarang. \\ *Email: harianingsih@unwahas.ac.id
}

\begin{abstract}
Abstrak
Senyawa Fe merupakan logam berat yang dapat menyebabkan kerusakan sel dan berbahaya bagi tubuh jika terdapat berlebihan dalam air. Kandungan logam berat dan mineral dalam limbah batik terutama Fe yang nantinya terbuang di lingkungan harus sesuai dengan ambang batas yang ditentukan oleh peraturan pemerintah yaitu $0,3 \mathrm{mg} / \mathrm{l}$ dalam air. Perlu adanya inovasi pembuatan membrane mikrofiltrasi Fe dengan biaya yang murah serta efektif. Adanya penelitian ini bertujuan untuk mensintesis membrane mikrofiltrasi Fe yang berlebih dalam limbah batik. Hasil penelitian yang telah dilakukan diperoleh bahwa membrane mempunyai ukuran pori 1mili micron sehingga selulosa asetat cassava dapat dikategorikan sebagai membrane mikrofiltrasi. Hasil penelitian yang telah dilakukan dengan massa membrane selulosa asetat cassava 500mg diperoleh prosentase reduksi Fe yang sebesar 58,74\% dengan waktu kontak yang diperlukan 15 menit, reduksi Fe mencapai 43,26 dengan waktu kontak 10 menit dan prosentase mencapai 31,09 dengan waktu kontak 5 menit. Kinerja membrane selulosa asetat cassava juga dapat dilihat dari prosentase rejeksi Fe optimum pada 32,86\% dengan massa membrane selulosa asetat cassava $500 \mathrm{mg}$ dan waktu kontak yang dibutuhkan 60 menit. Dari hasil penelitian tersebut dapat disimpulkan bahwa membrane selulosa asetat cassava dapat dijadikan rekomendasi untuk mikrofilter Fe pada limbah batik.
\end{abstract}

\section{Kata kunci : limbah batik, membran, mikrofiltrasi, selulosa asetat cassava}

\section{PENDAHULUAN}

Membran merupakan penghalang antara dua fasa atau komponen yang mempunyai sifat selektif sehingga memungkingkan fasa atau komponen tersebut menembus dengan cepat karena pengaruh gaya penggerak atau lebih dsering dikenal dengan driving force. Faktorfaktor yang berpengaruh dalam driving force antara lain: gradien konsentrasi $(\Delta \mathrm{C})$, gradien tekanan $(\Delta \mathrm{P})$, gradien suhu $(\Delta \mathrm{T})$ dan gradien potensial listrik $(\Delta \mathrm{E})$. Teknologi pemanfaatan membrane mempunyai keunggulan dibanding proses mikrofiltrasi yang lain, sehingga sangat memungkinkan untuk teknologi ini terus dikembangkan.

Beberapa keuntungan pemanfaatan teknologi membrane adalah bahwasanya pemisahan dapat dilakukan secara kontinyu, energy yang digunakan lebih rendah sehingga biaya produksinyapun semakin murah, proses ini dapat dikolaborasikan dengan proses mikrofiltrasi yang lain, proses up scaling yang mudah dan sifat-sifat serta variasi membrane dapat disesuaikan dengan senyawa tambahan yang digunakan. Akan tetapi teknologi ini tidak selalu menguntungkan. Beberapa kelemahan pemakaian teknologi membrane ini adalah terjadinya polarisasi konsentrasi atau biasa disebut dengan "fouling", usia membrane juga relative pendek sehingga penggunaan harus diganti pada periode waktu tertentu (Mulder, 2000 dalam Harianingsih, 2017).

Membran dapat dibedakan berdasarkan karakteristik bahan dasar, struktur morfologi dan metode serta prinsip pemisahan yang dilakukan (Mulyono dkk., 2007). Membran pada penelitian ini terbuat dari selulosa asetat yang mempunyai karakteristik struktur morfologi asimetris. Membran yang terbuat selulosa asetat rata-rata mempunyai ukuran 0,01 hingga 0,1 milimikron atau yang lebih dikenal dengan membrane ultrafiltrasi dan 0,1-1 untuk ukuran membrane mikrofiltrasi (Mulyono dkk., 2007). Metode yang dilakukan untuk membrane mikrofiltrasi yang mempunyai sifat morfologi asimetris dapat digunakan metode inversi fasa dengan presipitasi imersi. Inversi fasa merupakan proses perubahan bentuk polimer dari fasa cair menjadi fasa padat yang terkendali sehingga terjadi pemadatan. Awalnya ada transisi dari fasa cair ke dalam fasa dua cairan (liquid-liquid demixing) sehingga terjadi proses pemadatan. (Lindu dkk., 2008).

Pada saat proses demixing yang terjadi adalah salah satu fasa cair yang kaya akan kandungan polimer akan membentuk padatan 
sehingga terbentuk matriks padatan. Membran yang dihasilkan dari proses demixing ini akan menghasilkan membrane dengan porositas yang tinggi dan distribusi porinya luas. Presipintasi Imersi yang merupakan bagian dari inversi fasa mencetak larutan polimer pada penyangga membrane sehingga saat padatan dicelupkan dalam koagulan yang tidak ada pelarutnya akan terjadi pertukaran antara pelarut dan non pelarut (Natalia dkk., 2003).

Membran mikrofiltrasi itu sendiri sebagai lapisan semipermiabel dapat memisahkan komponen campuran dengan perbedaan sifat fisik dan sifat kimia. Sifat membrane yang selektif menyebabkan membrane menjadi penghalang dua fasa, yaitu fasa yang masuk (disebut dengan fasa umpan) dan fasa yang menembus/melewati membran (disebut dengan fasa permeat). Pada proses mikrofiltrasi ada juga fasa yang tidak dapat menembus membrane atau yang biasa dikenal dengan retentant (Fane, 2000 dalam Harianingsih, 2017). Skema pemisahan membran ditunjukkan pada gambar 1 .

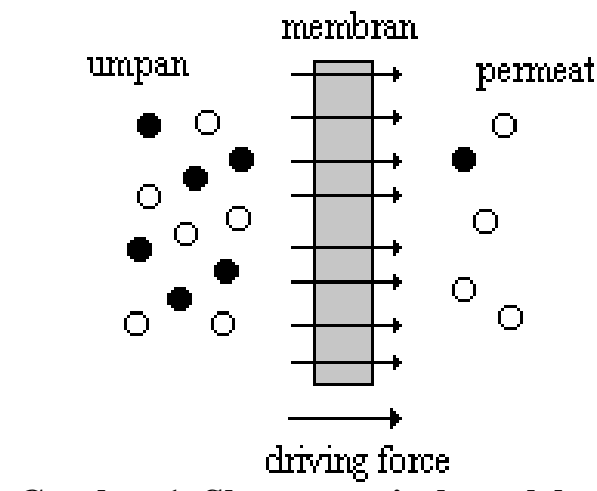

Gambar 1. Skema pemisahan oleh membrane

Senyawa Fe merupakan logam transisi yang memiliki nomor atom 26 dalam sistem periodeik unsur. Fe menempati urutan sepuluh besar sebagai unsur terbanyak yang ada di bumi. Senyawa $\mathrm{Fe}$ mempunyai peran penting dalam kehidupan manusia. Di dalam tubuh $\mathrm{Fe}$ berfungsi sebagai fasilitator oksigen dan $\mathrm{He}$ (hemoglobin). Tubuh manusia mendapat asupan Fe bisa dari sayuran yang dimakan ataupun air minum. Akan tetapi peran Fe ini akan menjadi tidak efektif jika jumlah Fe yang masuk ke dalam tubuh melebihi ambang batas yang telah ditentukan. Jika Fe ini berlebihan dalam tubuh yang terjadi adalah timbulnya kerusakan hati dan sel, jantun dan organ tubuh lainnya yang pada akhirnya dapat menjadi penyebab kematian. Selain pada tubuh, bahaya Fe pada lingkungan sekitar antara lain dapat menyebabkan kerak pada beberapa benda, noda pada pakaian dan lain sebagainya (Septiana dan Putri, 2015).

Senyawa Fe juga terdapat pada limbah batik. Limbah batik biasanya tidak diolah kembali melainkan dibuang di sungai atau tempat pembuangan. Kandungan $\mathrm{Fe}$ dalam limbah batik yang terbuang harus sesuai dengan ambang batas yang ditentukan oleh PERMENKES Nomor 492/ Menkes/ Per/IV/2010 dimana didalam peraturan tersebut disebutkan bahwa Kadar besi maksimal yang diperbolehkan dalam air adalah $0,3 \mathrm{~mol} / \mathrm{liter}$. Berlebihnya senyawa $\mathrm{Fe}$ dapat diminimalisir dengan proses mikrofiltrasi menggunakan selulosa asetat cassava. Selulosa asetat cassava dibuat dari bahan ketela pohon yang aman untuk lingkungan. Untuk itu tujuan dari penelitian ini adalah mengetahui ukuran pori membrane selulosa cassava asetat melalui Scanning Electron Microscopy (SEM), mengetahui pengaruh waktu kontak proses terhadap prosentase reduksi $\mathrm{Fe}$ pada limbah batik artifisial, mengetahui kondisi optimum membrane selulosa asetat terhadap prosentase rejeksi Fe pada limbah batik artifisial.

\section{METODOLOGI}

\subsection{Bahan}

Sari ketela pohon, amonium sulfat, sukrosa, $\mathrm{CH}_{3} \mathrm{COOH}$, stater Acetobacter xylinum, aquades, air, aseton, $\mathrm{Fe}(\mathrm{Cl})_{3}$, asetat anhidrida, carboxymetyl cellulosa $(\mathrm{cmc})$, fornamida

\subsection{Alat}

Alat penguji membran berupa tabung yang disebut dengan Dead End, diameter $20 \mathrm{~cm}$. Prinsip kerja alat ini adalah dengan mengalirkan umpan dan udara ke dalam tabung, kemudian membran di pasang pada dasar tabung dan dieri aliran keluar untuk permeat (fasa yang melewati/ menembus membran). Tabung Dead End dapat dilihat pada gambar 2. Alat lain yang digunakan antara lain gelas beaker, kompor listrik, magnetik stirer, loyang fermentasi, kertas koran, aluminium foil, autoclave, inkubator, SEM. 


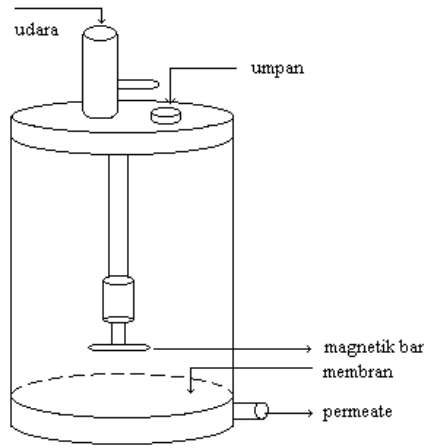

Gambar 2. Alat Dead End

2.3. Prosedur Kerja

\subsubsection{Pembuatan Membran Selulosa Asetat Cassava}

Pemanasan dilakukan pada $1000 \mathrm{ml}$ sari ketela pohon hasil penyaringan dituang ke dalam gelas beaker ukuran $1000 \mathrm{ml}$ yang telah dilengkapi dengan magnetik stirer, ditambah $100 \mathrm{~g}$ sukrosa, 5g Amonium sulfat dan diaduk hingga homogen. Kemudian diasamkan dengan $\mathrm{CH}_{3} \mathrm{COOH} 25 \%$ hingga $\mathrm{pH}=4$, tambahkan carboxymetil cellulosa (cmc) dengan konsentrasi 5\%, dipanaskan hingga mendidih. Kemudian campuran dalam keadaan panas dituang dalam loyang fermentasi dan ditutup dengan kertas koran. Setelah campuran berada pada kondisi suhu kamar, tuang stater acetobacter xylinum.

Fermentasi selama 14 hari pada suhu kamar hingga terbentuk pelikel.. Lapisan pelikel ditambah dengan fornamida kemudian dilarutkan dalam aseton dengan perbandingan 1 : 1 : 2. Campuran ditutup dengan aluminium foil dan diaduk dengan magnetik stirer selama 24 jam. Campuran yang telah homogen didiamkan selama 24 jam untuk menghilangkan gelembung. Setelah gelembung hilang tuang campuran di atas plat kaca dan cetak dengan pisau perata. Lapisan membran selulosa yang terbentuk dicuci menggunakan air.

\subsubsection{Pembuatan Limbah Batik Artifisial}

Menyiapkan aquadest seanyak 3 liter kemudian menyiapkan larutan $\mathrm{Fe}(\mathrm{Cl})_{3}$. Campurkan larutan dalam beaker glass kemudian aduk hingga homogen. Menghitung konsentrasi Fe dilakukan dengan menggunakan persamaan :

$\mathrm{Fe}(\mathrm{mg} / \mathrm{L})=\mathrm{C} \times \mathrm{fp}$

Dengan $\mathrm{C}=$ konsentrasi yang diperoleh dari hasil pengukuran

$\mathrm{fp}=$ faktor pengenceran

\subsubsection{Uji Dead-End}

Membran selulosa asetat cassava yang akan diuji dipotong dengan bentuk lingkaran dengan berat $100 \mathrm{mg}, 200 \mathrm{mg}, 300 \mathrm{mg}$, 400mg dan 500 mg. Membran selulosa asetat cassava diletakkan di bagian bawah alat penguji yang dilengkapi dengan penyaring pada bagian bawah membran dan seal sebagai penahan membran. Alat dead end ditutup dengan rapat, lalu larutan media yang mengandung $\mathrm{Fe}$ dimasukkan ke dalam dead end kemudian ditutup rapat. Tekanan sebesar 1 bar dialirkan, kemudian hasil saringan yang keluar pada bagian bawah diukur volumenya. Waktu kontak dengan variasi 5 menit, 10 menit dan 15 menit.

\section{HASIL DAN PEMBAHASAN}

Membran berdasarkan bentuk morfologi asimetrisnya mempunyai dua ukuran pori yaitu ultrafiltrasi sebesar 0.01-0.1 milimikron dan mikrofiltrasi 0,1-1 milimikron. Pada penelitian ini melalui metode uji Scanning Electron Microscopy (SEM) dihasilkan membrane selulosa asetat cassava dengan ukuran kurang lebih 1 milimiron yang dapat dilihat pada gambar 3. Karena ukuran selulosa asetat cassava yang dihasilkan kurang lebih 1 milimikron maka selulosa asetat cassava dapat disebut sebagai membrane mikrofiltrasi. Hal ini sesuai dengan teori yang ada pada uji penelitian Mulyono dkk (2007).

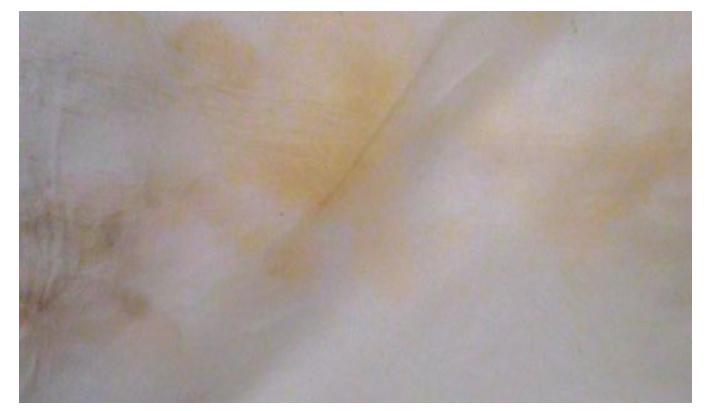

Gambar 3. Membran selulosa asetat cassava

Pada gambar 3. menunjukkan membrane selulosa asetat cassava dengan ukuran pori yang teridentifikasi melalui foto SEM adalah sebesar 1 mili micron. Ukuran ini memperlihatkan bahwa membrane selulosa asetat cassava hasil penelitian merupakan membrane mikrofiltrasi yang dapat digunakan untuk filtrasi $\mathrm{Fe}$ pada limbah batik artifisial. Membran selulosa asetat cassava yang dihasilkan berwarna putih kekuningan. 
Indikator membrane dapat memfilter $\mathrm{Fe}$ adalah dengan menghitung prosentase penurunan (reduksi) Fe pada waktu kontak tertentu. Pada penelitian ini diperoleh data terjadi penurunan konsentrasi $\mathrm{Fe}$ mencapai $58,64 \%$ dengan waktu kontak 15 menit dan massa membrane selulosa asetat cassava 500 mg. Variasi massa selulosa asetat cassava antara lain $100 \mathrm{mg}, 200 \mathrm{mg}, 300 \mathrm{mg}, 400 \mathrm{mg}$ dan $50 \mathrm{mg}$. Gambar grafik hubungan antara waktu, massa selulosa asetat cassava dan reduksi Fe. Reduksi Fe dipengaruhi oleh waktu penyerapan selama umpan limbah batik dimasukkan ke dalam alat Dead Ed. Semakin lama tingkat penyerapan $\mathrm{Fe}$ semakin baik

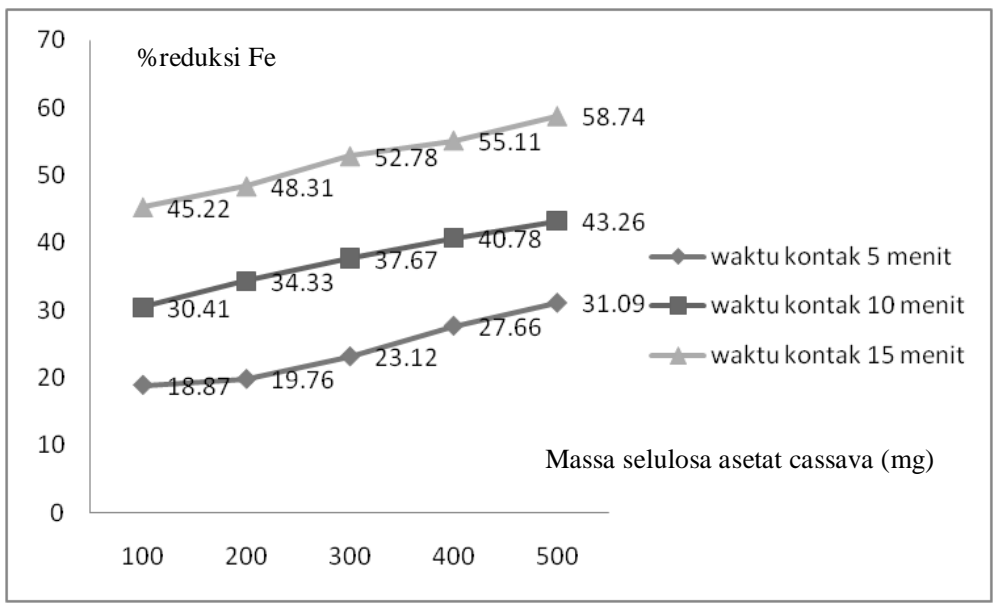

Gambar 4. Grafik Hubungan waktu kontak, massa selulosa asetat cassava dan \% reduksi $\mathrm{Fe}$

Pada gambar 4 yang memperlihatkan hubungan antara massa membran selulosa asetat cassava dengan penyerapan $\mathrm{Fe}$ dapat dilihat bahwa dengan bertambahnya massa maka prosentase penyerapan $\mathrm{Fe}$ semakin besar. Hal ini juga didukung dengan waktu kontak antara membran selulosa asetat dengan larutan batik artifisial yang mengandung $\mathrm{Fe}$, bahwasanya semakin lama waktu kontak maka prosentase penyerapan $\mathrm{Fe}$ juga semakin besar. Prosentase reduksi $\mathrm{Fe}$ yang sebesar 58,74\% dengan waktu kontak yang diperlukan 15 menit, reduksi $\mathrm{Fe}$ mencapai 43,26 dengan waktu kontak 10 menit dan prosentase mencapai 31,09 dengan waktu kontak 5 menit. Pada gambar 4 memperlihatkan bahwa penyerapan ion $\mathrm{Fe}$ untuk variasi massa membran mengalami peningkatan prosentase reduksi Fe seiring dengan bertambahnya waktu kontak. Titik optimum pada variasi variabel tersebut adalah pada waktu kontak 15 menit dengan massa membran selulosa asetat sebesar
$500 \mathrm{mg}$ yaitu prosen reduksi $\mathrm{Fe}$ sebesar $58,74 \%$. Logam $\mathrm{Fe}$ dapat terserap pada membran selulosa asetat cassava karena adanya gaya Van der Waals yang melekat pada permukaan membran kemudian membentuk ikatan kovalen. Pada membran tersedia ruangruang dalam struktur selulosa asetat cassava yang menyebabkan ion logam $\mathrm{Fe}$ masuk ke dalam ruang struktur tersebut. Pembentukan senyawa komplek terjadi pada mekanisme penyerapan $\mathrm{Fe}$ dengan selulosa asetat cassava. Selulosa asetat cassava berperan sebagai ligan karena memiliki gugus aktif hidroksil yang dapat menyumbangkan sepasang elektron bebas pada ion logam Fe. Sedangkan ion logam Fe berperan sebagai atom pusat dalam pembentukan senyawa kompleks.

Hubungan antara nilai rejeksi membran dengan waktu dan variasi massa membran dapat dilihat pada gambar 5 . 


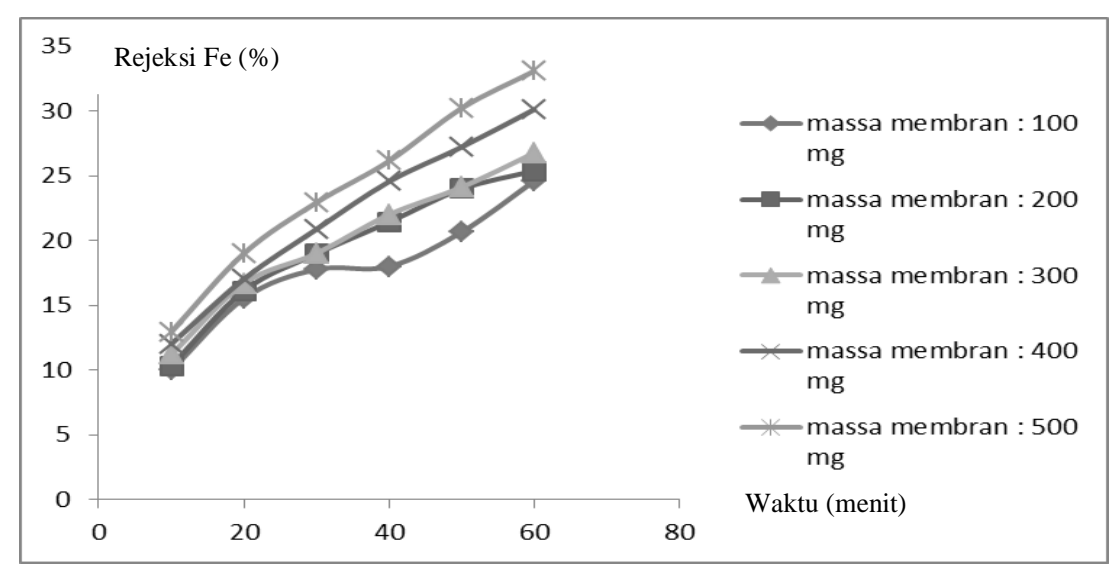

Gambar 5. Grafik Hubungan waktu, rejeksi Fe dan Massa membran

Pada gambar 5 memperlihatkan kemampuan membran selulosa asetat cassava dalam proses penyerapan $\mathrm{Fe}$ dari limbah batik artifisial tergantung dari kemampuan membran merejeksi partikel Fe. Pada penelitian ini digunakan umpan limbah batik artifisial dengan konsentrasi Fe 20 $\mathrm{mg} / \mathrm{l}$. Dalam waktu 60 menit diukur setiap 10 menit nilai prosesntase rejeksi Fe. Perubahan prosentase refeksi Fe dapat terjadi karena adanya penyumbatan pori (fouling) membran selulosa asetat cassava yang dapat menahan partikel $\mathrm{Fe}$ terlarut dalam membran. Pada penelitian diperoleh prosentase rejeksi $\mathrm{Fe}$ pada $32,86 \%$ untuk massa membran selulosa asetat cassava $500 \mathrm{mg}$ dan waktu 60 menit.

\section{KESIMPULAN}

Berdasarkan hasil penelitian maka dapat diambil beberapa kesimpulan sebagai berikut :

1. Membran selulosa asetat cassava yang dihasilkan dari penelitian teridentifikasi melalui foto SEM mempunyai besar pori 1 milimikron dan dapat dikategorikan sebagai membrane mikrofiltrasi yang dapat menyerap Fe pada limbah batik artifisial.

2. Pada proses Dead End dihasilkan massa optimum membrane selulosa asetat cassava adalah 500 mg dengan waktu kontak 15 menit dan prosentase reduksi Fe sebesar 58,64\%.

3. Kemampuan membrane selulosa asetat cassava untuk dapat menyerap Fe ditunjukkan dengan nilai rejeksi Fe yang optimum pada massa membrane $500 \mathrm{mg}$ dan waktu 60 menit sebesar $33,09 \%$.

\section{UCAPAN TERIMAKASIH}

Terimakasih peneliti ucapkan kepada DRPM Kemenristekdikti untuk pendanaan melalui Skema Penelitian Dosen Pemula.

\section{DAFTAR PUSTAKA}

Chyntia dan Yuliani, (2016), Penggunaan Membran Nata de Coco Sebagai Bahan Membran Selulosa Asetat, Prosiding Simposium Nasional Polimer V, ISSN 1410-8720. Pp. 203-208.

Harianingsih dan Suwardiyono, (2017), Pengaruh Penambahan Gliserol Terhadap Tensile Strenght dan Elongation at Break Edible Film dari Nata de Soya, Jurnal Inovasi Teknik Kimia, Volume 2 No. 1.

Lindu, Muhammad., dkk., (2008), Sintesis dan Uji Kemampuan Membran Selulosa Asetat Nata de coco sebagai membrane Ultrafiltrasi Untuk Menyisihkan Zat Warna pada Air Limbah Artifisial, Jurnal Membran, Vol 4. No.4. pp. 107-112.

Mulyono, Tri., dkk., (2007), Potensial Membran Nata de coco sebagai Material Biosensor, Jurnal Ilmu Dasar, Vol. 8 No.2. pp. 128134.

Natalia, S. Totok, A., Atie, S., (2003), Sintesis dan Optimasi Membran Selulosa Asetat pada Proses Mikrofiltrasi Bakteri, Unitas. Pp. 29-45.

PERMENKES : 492/ Menkes/Per/IV/2010

Pinnata, rachmida dan amayanti, Alia., (2016), Pemanfaatan Selulosa Asetat Enceng Gondok Sebagai Bahan baku Pembuatan Membran Untuk Desalinasi, Jurnal Ilmu lingkungan ITS, Pp.1-6.

Safriani., (2000), Produksi Biopolimer Selulosa Asetat dari Nata de Soya, Pascasarjana IPB.

Septiana Hadi dan Putri, (2015), Pembuatan Kitosan dari Cangkang Keong Mas untuk Adsorben Fe pada Air Sumur, Perpustakaan .uns.ac.id. 